REFLECTIONS:

NEUROLOGY AND THE

HUMANITIES

Section Editor

Michael H. Brooke, MD

\section{Ferris Wheels, Fly Fishing, and the Dumping}

From that height, you could see rotten wood where the end grains lay exposed.

"What do you think, cool, or what?"

Sarah grunted. There was no really good answer. There was a world far more revealing, disciplined and chaotic, cruel and enticing for her. Cool or fun were not the right words, not now.

The incoming tide smelled crisp, mildly sulfurous and faintly sick. At the wheel's apex you could see off to the towers of the Seabrook Nuclear station, flocks of birds followed school stripers that in turn chased sand eels, and behind you could see the great dark of the Gulf of Maine. Each revolution revealed new twilight skirmishes erupting up and down the marsh's watery fingers, fish were stalking and dying all around them.

Sarah observed all this. Charlie remained oblivious, talking instead of skee ball, how many tickets it takes to win a stuffed clown, and the subtle differences between fry dough available at Revere, Hampton, Rehoboth, Ocean City, and Nantasket beaches. She heard none of it. you a long ride; there's not a lot of business and in no hurry to move you off or on. Tonight, Sarah Morgan sits with Charlie Darby, looking west to a late June sunset. Fifty feet below them is a chair loaded with six sacks of sand the old man threw on as a counterbalance. The couple are about to break up.

"Sure is something."

"What?"

"The marsh, the river, the sunset."

Charlie slapped a greenhead fly intent on sticking him, sucking his blood. Their nagging bites and swarming were on the wane for the day and already the first scout mosquitoes moved, ready to reinforce. They targeted Charlie. Sarah ignored them; with repellant on, they left her alone. She instead thought of the sand, did the math, three $50 \mathrm{lb}$ sacks per body. The old man had overshot her; he nailed Charlie.

"And this thing."

"Isn't it fun?"

He points to the wheel, some of the cables slack and the turnbuckles rusted in place. Birdcrap streaked the stanchions, the paint plaques bubbled in places, grease and rust drizzled down the housing.

\section{Fly Fishing}

A day earlier, Sarah had paddled the maze of linked marsh waters around the base of the Ferris wheel with Charlie's cousin Mark. Charlie and his sister trailed behind in a second canoe, but the bugs were bad, they turned back. Mark hung a lit mosquito coil in a tin can off the canoe's mid spar. When she climbed in, just seated and with the boat still rocking, she turned to barely catch a can of repellant thrown her way.

"Sarah. Spray it on."

She did and they paddled further into the grass marsh. The seagrass soon obscured everything but the waters and the small submerged canyons of crumbling mud walls, lined with roots and sea-grape, green crabs, clusters of mussels and occasional clams. A pair of horseshoe crabs crawled in tandem below, timeless creatures moving through the sands and mud.

Behind Mark, a fly rod stuck up like a conduction rod on a bumper car. She'd never seen anyone fly fish and Mark said he'd show her. After the paddling left them nearly sweating, he threw the anchor, chainlink 
rattling over the edge, and they sat at a confluence of watery paths in a pool the size of a tennis court.

"The fish will be here soon."

He held out a sandwich, and the canoe rocked as Sarah turned in her seat and took it from him, meeting him halfway.

"What do you want to do with yourself?"

"I'm going to grad school, out west."

"For what?"

"Paleontology."

He shrugged, like he didn't know what she meant.

"Fossils."

"I know what it means."

She immediately regretted clarifying.

"And you?"

"No grad school, I'm going out west too."

"Why?"

"Explore. Fish. I don't know. Never been out of New England. See the salmon run. Catch a steelhead, climb a mountain. No more Monadnock."

They passed some silence, it didn't make him uncomfortable. Not like Charlie, who abhorred it. Her father saw that and when he told her, the comment stuck fast. A slow and steady erosion formed around it. At first she couldn't meet Mark's stare but then she held her own.

"What are you looking at?"

"You."

She was uncomfortable.

"You know what Monadnock means? A mountain that comes out of nowhere, just sticks straight up. Straight out of a flatland."

"Yeah, you're ready for that grad school."

In the silence, looking at Mark, it dawned on her-the gift of three different sizes of matching $\mathrm{Ca}$ ribbean Blue suitcases from her parents was in encouragement of her leaving UNH and, more importantly, Charlie.

"Beer?"

He passed a bottle. He plucked at salami stuck in his teeth.

"You like Chuck?"

"I guess. I mean we go out."

"See I figured you different, like a girl who is just about as miserable as can be. Chuck does that to girls, goes for the smart ones and makes them miserable. They fall for him, all his kid stuff. He has a shtick. I've seen it before. He would have dumped you by now if you weren't for the..."

He didn't say it, but she knew what he meant. Maybe he pitied her, with her multiple sclerosis. He thrilled to that role of injecting her medicine, nagged her about forgetting. But when Charlie said "You better not do ..."; it's when he said that, more than once, she knew it would end. But how to do it?

"That so?"

Suddenly he sat up, beneath them a cloud of small bait, moving out with the tide. Mark found the rod, unhooked the fly, a long white and blue thing.

"They call this a streamer, and it looks like those." He pointed in the water at the moving schools balled-up like starlings on a field of just-cut wheat, now and then shifting, en masse, turning at threats and for opportunities.

Half kneeling on the seat, within three feints, line shot toward the broad part of the pool, he moved the streamer through the water, a foot at a time, and his rod bowed and he shouted out. Sarah had never seen a fish caught with a fly, but in half a minute Mark had pulled to hand a thick-barreled fish as long as her forearm, striped down its sides and wide-jawed, and within a second or two he had it unhooked and back in the water.

"Your turn."

He handed the rod over.

"I don't know how to fish!"

"Only a fool, or Chuck, couldn't catch a fish here, now, this moment."

"Hold the line in your left hand, put your index under the line and hold the cork with your right. Lift the rod tip straight, like I did, and then push it forward; while you're doing that, let the line out through your left hand."

Sarah did just as he said and a mess of tangled line fell just overboard.

"Nah-don't worry about it, let the tide pull it."

Line slowly peeled off from the floor of the canoe, out over the gunwale moving toward the center of the pool.

"When all that line's unwound, just pull it back like you saw me."

She did as he said and then there was a heavy tap and the rod bent hard and then nothing.

"OK, there's a big strike, but you have to set the hook, so when you get that strike next time, don't let go of the line, pull your rod back fast, set the hook."

More line retrieved, another strike, she did as he said and the weight stayed. A heavy thump-thump of the fish, and the rod moved in concordance, the weight of something alive and fighting.

"He's bigger, let go of some of the line through your fingers, run him a little, and when he stops running, reel him. Or her."

It was another three minutes or so of give and take before the fish was swimming under the canoe, broad stripes down its side, dorsal fins high and spread with centurion spikes in its great fear and then in a terrific twist, gone, before she even had a chance to touch it.

"Hah. You lost, not to worry, there's more here..." 
Terns now bombarded the waters. Larger fish were boiling and rolling and stunned bait floated to the surface.

"Do it again, cast again ... .catch another."

\section{The Dumping}

"Sarah... Sarah ... you hear me, what do you think, we get a Fisherman's Platter on the way back, some fried clams, some of those tempura shrimps, I know this great fry-clam place?"

"Charlie. There's something I want to tell you."

"You don't want fried food, I knew it, well pizza then, maybe some chicken nuggets, a happy meal?"

"No you dope, how do I put this?"

The wheel seemed to move even slower, and now and then, when the sandbags were directly above them, a tiny leak rained down from a rent in one of them, always on Charlie. He felt it, even ran some through his fingers, but never saw where it came from.

"When I go out West, when I leave, I want to be alone. Do you know what I mean?"

That silenced Charlie. That first great silence they'd had. High on that slow turning wheel, creaking and groaning, the chatter of the winch engine and the rasp of the chain driving the whole thing, the smoke coming off the attendant's next cigarette below.

Sarah thought of Mark, his simple way, his calm confidence and his hands on hers as he helped her remove the well-set hook on her last fine striper. How it made her stop and let him guide her, how to ask for more.

And then she thought again of the wheel, that slow crumbling miserable wheel. And how this would probably be the first and last time she would ever break up on a Ferris wheel. She knew later, not now, but later, she would write Charlie and wish him well, maybe years later, in a Christmas card or an e-mail, and they might find this scene amusing, but not now. Charlie was hurt, and although she cared for him on some level, this hurt was necessary.

It wasn't long before she wondered how long the guy would run the wheel. She wanted to call out to him, tell him to let them off. But she didn't; some things can't be rushed. She wished she was out West, where the salmon ran, where the mountains stretched on forever, where she would find other silent worlds trapped in rocks and shale. 


\title{
Neurology
}

\author{
Ferris Wheels, Fly Fishing, and the Dumping \\ Michael John Doherty \\ Neurology 2008;71;2015-2017 \\ DOI 10.1212/01.wnl.0000336977.18540.b3
}

\section{This information is current as of December 8, 2008}

\section{Updated Information \& Services}

Subspecialty Collections

Permissions \& Licensing

Reprints including high resolution figures, can be found at: http://n.neurology.org/content/71/24/2015.full

This article, along with others on similar topics, appears in the following collection(s):

Multiple sclerosis

http://n.neurology.org/cgi/collection/multiple_sclerosis

Information about reproducing this article in parts (figures,tables) or in its entirety can be found online at:

http://www.neurology.org/about/about_the_journal\#permissions

Information about ordering reprints can be found online:

http://n.neurology.org/subscribers/advertise

Neurology ${ }^{\circledR}$ is the official journal of the American Academy of Neurology. Published continuously since 1951, it is now a weekly with 48 issues per year. Copyright. All rights reserved. Print ISSN: 0028-3878. Online ISSN: 1526-632X.

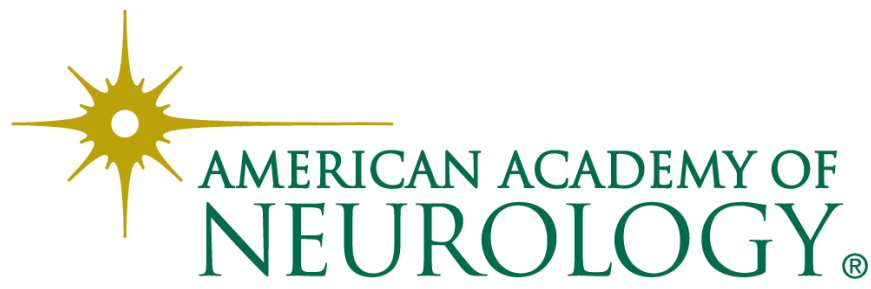

